\title{
Anthropology an Intellectual Tradition and Contemporary Relevance
}

\author{
Hina Qanber Abbasi
}

Department of Humanities and Social Sciences, COMSATS Institute of Information Technology, Lahore, PAKISTAN

\begin{abstract}
The notion of invariable human nature has been an important subject of enquiry and continues even in the modern times. The relative malleability has been argued in recent centuries by the early mechanists Thomas Hobbes and Jean Jaques Rousseau. As Rousseau stated "We do not know what our nature permits us to be" thinkers like Hegel and Marx argued against invariable human nature. Still more recent scientific perspective such as behaviorism, modern psychology claims to be neutral in this regard. To them human's origin posses underlying mechanism, having capacities for change and diversity, which ultimately is a violation of the classical philosophical anthropology. The resulting fragmentation, as a consequence, has impacted intellectual enquiry. It is pertinent to say that the new dialectics of change fail to comprehend ethics and moral values, which are associated with higher aim, realization of good life, politics implied to reach agreements on better conditions, and realization of rationality (which engages in enquiry to realize the common good), thereby jeopardizing place of humanity in the cosmos. The new global forces have made people powerless, reduced them to a cog in the environment of uncertainty, ultimately leading to a looming war of all against all that is inexorably destroying the conditions for life. The policies and characteristics of the modern state and their bureaucracies rather accelerate these sequences which may lead to eradication of humanity. In this paper we try to resolve issues of legacy, along with the new dialectical patterns of globalization.
\end{abstract}

Key word: anthropology, intellectual enquiry, dialectics, globalization

\section{INTRODUCTION}

The current controversy against religion may be referred to the post globalization; a large scale socio-cultural transformation also required expert knowledge to eliminate dogmas and superstitions in traditional societies. The expert knowledge, including that of theologians, as they become more specified, 'creed define religious identity, related to national, ethnic or social class characteristics, moreover they enhance divide and provide basis for the cleavages even they used to abused publically, the faith of other sects. Superstition and irrational dogmas dominate the social life and vastly increase a gap between the society and the ordinary person. Personal life become more; infused 'with uncertainty, hazardous, and 
risky, theologians lack rationality and expert knowledge; they speak to divide, therefore planting hatred and extremism.

Lacking reflexivity, they have increased uncertainty and risk. Society in Pakistan may be rightly or wrongly characterized as the, risk society; where belief system is threatened and in the language of gun, and suicidal attacks.

\section{Citations}

The core of all critical thinking, indebted to western philosophy, an intellectual tradition. Philosophy approached questions rigorously human in nature. Functioning in specific sphere, opting for both cultures, including metaphysics, science and struggle for survival. Whatever it offers received equivocal reception. Therefore philosophy must not be phrased as;' unanswered questions".

From the very dawn of human consciousness philosophy's dominant interest have been to discover universal methods of knowing, and an absolute form of reality, which can be the source of human good.

Being a part of human, activity and human culture philosophy's main emphases have been belligerently formidable. Human development owed to the amazingly broad and; 'esoteric question which always have implied profoundly by the philosophers.

From Socratic famous saying; an un-examined life is not worth living, to Plato's classic; allegory of the cave', and virtue as the guiding principle for humans and states. Moreover all subsequent western philosophy remained under the influence of Aristotelian universalism of ethics and politics. Philosophy as a whole is in the indebtness of Aristotle's dictum that; man is apolitical animal, and if he is without state, he is super human' or subhuman. 'In his own words; the science that studies the supreme good for man is politics,'. The concept of individualism is first coined by Niccolo Machiavelli, revived later on by Thomas Hobbes, in a first ever systematic approach towards the subject matter of philosophy, certainly acquired him the 21,st century philosopher title, that he led directly to the issues $\mathrm{R}$ elated to the 21,st century humans such as the; scarcity of; the resources', ;conflicts over the resources,' the new parameters of ethics,; 'power the sole deciding factor to control, manage and distribute resources.

HEGEL is both classical and modern at the same time. To him ,human activity and its reflections may be explained by both -science and ethics .questions like;; what should I do 'or what ought I do,; are alien to science, but are very much a part of life in the same token question like ,; what am I, what should I be,' are alien to ethics but are a part of science. As Paul blacklegged, rightly analyze that Hegel's great contribution to moral theory started from a, historical comparison of two different social context of modern and classical conceptions of ethics, asking how Germans at the junction of the 19th century are different from ancient Greeks. To solve this dilemma by suggesting a historical, dialectical model of human, pursuing that ethics is related to the more contentious resolvement of,'what human beings are', only by resolving this the modes of life suited to their nature can be universalized that ', communities grow and consolidate in to an international community'.

It was during 1844, when the Silesian weavers rose against the atrocities of their masters, Marx gave credit to this movement for he became a; Marxist'. He claimed that,' communists do not preach morality'.

Marx, s; ethical judgments' are assimilated with revolutionary struggle of the proletariats against exploitation. Collective struggle evolves the meaning of freedom, socialized 
human beings, that individual cannot become free in isolation from others. Moreover, Marxism both as a social science and as a critique dismisses the bourgeois, dictum of; is' and; ought' questions. To him, a universal good, might not be promoted by moral attitudes, rather he promoted the idea of a class based morality which is more genuine, universal and historical in its purpose.

John Dewey puts it we long amid a troubled world, for perfect being.'

John Dewey, as a historian rightly commented that, we should keep deep, faith and hope' in a continuing moral progress of man. More over it should be viewed within the context of a, post future continuum,' to him. Only a; direction of movement', on historical events, could best perceive moral development.

to him,; the quest for certainty,' is always there, to discover a form of reality that is absolute, trustworthy, and the source of and preserver of human good;'

Is globalization a quest for certainty? The philosophy of globalization has many meanings, definitions, and descriptions. What is worth mentioning is globalization really worth or its marketing going well. Is it successful in providing a frame work for good life? Is it justified to say that Hobbesian; leviathan 'with; resolute-competitive' method have been reinvented. Again armed with new scientific approaches to achieve scientific certainty.

Does globalization,; an attempt to escape predicament involves a return to classical Greek virtue ethics'. Or an Hegelian attempt to develop; non-egoistic forms of human relations on the basis of virtue and ethics that goes beyond the limits of liberalism.

Do all the theories such as social contract theory, Kantianism and even modern virtue ethics can all be understood as a philosophical quest to provide logical frame work of how to formulate common good in a world of egoistic individuals?

Did we escape, max sterner who is ready to deny the concepts of nation, state, humanity and any mechanism of moral ideology which can overcome human egoism including communism.

The oldest and most important questions refer to human nature what these characteristics are what causes them? Humans tend to have them naturally independent of any cultural influence and socialization. The nature versus nature is well known inclusive debate since so rates, which turned philosophy from study of heavens to the study of Anthropos the real subject matter of philosophy. 1 Human Nature,From Wikipedia.p1

The Greek approaches and what it means to be human form an important domain of inquiry and have important implications in anthropology ethics and politics especial connection between human nature and divinity, raises another significant question that is human nature causes Jacques Rousseau and nineteenth century thinkers such as Hegel and Marx argued against ethics and politics. The more recent scientific approach, a neutral approach they stress on underlying human mechanism or to demonstrate capacity for change and diversity which established an argument to challenge teleological concept.

A review of the classical and a modern approach the standard notion of the ethics and politics are still to be in anthropological explanations. This debate joins the growing number of anthropologists who have recently argued "that moralities 'ethics should be a social phenomenon"; of much interest for the discipline. Human nature is such a substantial and complex phenomenon which leads; therefore to numerous perceptions and different points of views. Socrates; sole efforts which uncover; truths about human nature remain an intellectual tradition and lasting innovation. 3 great philosophers; Socrates 111 p.1

He has spent most of his time to help people to live life; in conformity with their true nature. That is the critical self assessment; of one; purpose in the cosmos. True to his teachings that; unexamined life is not worth living 4 Plato, '.apology; 38a 
Socrates is there even today. It seems time has not changed much in this regard; a modern Socrates might raise the question like what causes sectarianism. What is religious extremism 3 and how to bring peace? It was Socrates, the first anthropologist, who brought the lasting innovation to the intellectual tradition, the concept that the real subject matter of philosophy is the human. Prior to him the real concern of the thinkers were issues relating to the universe, how planets move, and how to please the god? He was the first to declare, that human is a reality, and the major questions related to him are about justice, love truth, courage beauty and knowledge. To him,' to know the good is to do the good,' 5 great philosophers. Socrates 111,p.1

Socrates s, spent most of his life, to help people, to live life in conformity with their true nature, only that is the critical assessment of one's purpose in the cosmos. True to his teachings that, unexamined life is not worth living; it seems time has not changed in this regard. Evil and injustices are there hundred times more in volume. A modern Socrates' questions might be as what war is, what terrorism is, what freedom is, what peace is, and what justice is. The questions are the same is any one there to seek answers. Is ours a civil society? It is this truth that must be made conscious and considered. Socrates despite having written nothing remains an enigma, an inscrutable individual who changed philosophy as it was conceived before.

Though having reputation for irony, each age, and each intellectual turn produces Socrates of his own. Socrates, a dialectical guide is the real founder of philosophical anthropology, probing serious human matters, marked with the ideas and methods are valuable and enlightened. Plato's words, say - we seek to understand not merely what he said and assumed but what his propositions imply- 6socrates. Stanford encyclopedia of philosophy,p.9

Moreover it was remained to Plato to establish resurgence of interest in Socrates. It was platonic dialogue and its aesthetic unity that provide us a consistent picture of Socrates. Thus dialogue in their literary context is like a brilliant constellation whose capital focuses is Socrates. Plato using literary devices and practice of textual critique remove the actual ambiguities in the subjects' philosophy investigates. ibid, p.11. 7

Though Socratic legacy engaged Plato in a serious literary investigation regarding ethics, morality justice and good life, he widened the scope of his philosophical enquiry by reflecting on social and political conditions of morality and became successful in establishing a moral theory. Justice, to him, is like an order and harmony, injustice is its opposite; to him, if justice is health, injustice must be its disease. Plato's ethics though high-minded moral principles also considers quality and efficiency as the mechanism for the self -contained community.8 Plato's ethics, an overview Stanford encyclopedia of philosophy, p16

What is remarkable in Plato is, the bold claim, true even in the 21st century to establish an appropriate political order transcending human ethics and moral values that only can be maintained by leaders with rigorous scientific training. What is not remarkable in Plato is the claim that humans are not born alike, the totalitarianism, and a rigorous cultural conservatism, while the concept of culture is completely associated with arthropod, the ethical refinement needs continuous cultural refinement.

Throughout most of his writings, Plato writes from view point of Socrates. However later on he incorporated his own views,; allegory of the cave,' might be such example 9plato,s views on human nature, using allegory of the cave as reference,p1

Like all other classical philosopher Plato maintains, virtues are the requisite skill and character traits of ethics. Ethics remains the most accessible branch of philosophy.10 Plato's ethics, an over view, Stanford encyclopedia of philosophy,p.2 
Classical philosophers believe that all human actions serve some purposes and to judge these purposes depends on their overall aim. What is important is the attainment of these aims Aristotle too, stressed the relationship between anthropology, ethics and politics. Aristotle is clear in this regard, in his book ethics, he searched for ultimate good that one should aim at being a human. Moreover, politics presupposes and have at least answers to the questions, what human are ultimate good of human lies in the activity in conformity with virtues, and if there is a choice, which the best and most complete.

Aristotle many centuries before Thomas Hobbes recognized the fact that humans are capable of higher rationality of participating in the governance. They can establish communities and capable of comprehending the world and their place in it these activities make them, deemed distinct human and consequently the development of the complete virtue11.arran gare, philosophical anthropology, ethics and political philosophy in an age of impending catastrophe, cosmos and history, the journal of natural and social philosophy,vol5,no2,2009,pp.2,3.

What is important is to identify those qualities that the ultimate good of humans are defined, and achieved. Ethics searched for what is the best kind of life for individual.

Politics of Aristotle established the universal fact that man is political animal to him the higher potential of humans cannot be realized until and unless he lives in a community. Only by living in such communities they become fully human. All subsequent western philosophy remained under the influence of Aristotelian universalism of ethics and politics, while opposing or refusing to acknowledge it, overtly and covertly made this framework as their point of departure. ibid,p.2

The renaissance thinkers though they were more interested in roman than Greek philosophy, their work would not have been possible without the frame work provided by Aristotle. They accepted, Aristotle's view that the potential of humanity could only be realized in self governing communities' civic and political humanism developed by Aristotle is continuously encompassing everything pertaining to humans that are the promotion of humanities, including anthropology. ibid,p.3

The famous philosopher Plato throughout most of his writings writes from the view point of Socrates however later on he incorporated his own views. Allegory of the cave might be such example. Plato proves that reality is not always what it seems14 Plato's views on human nature, using allegory of the cave as reference,p.1

Like all other classical philosophers; Plato maintains virtues are the requisite skills and character traits of ethics. Ethics remains the most; accessible branch of philosophy for many reasons to mention few of them all human actions serve some end or purposes and to judge these purposes depends on their overall aim. What is more important is the attainment of these aims which constitutes the quality of life to them life worth living entirely depends on the one's own nature and the conditions available. Plato's ethics,pp.2,3

They also stress on the role of the society on one's life its values and standards are important. Moreover these objectives are simultaneously influenced by external factors health, wealth, social standing and even good looks or sheer luck. As Plato being an idealist posited virtue, the guiding principle for humans and states; 16ibid

Machiavelli as being an realist figure it out as; dangerous 'delusion' to him; one should not keep examining how people should be The reality of the human condition lies in the fact; that humans are brutal, selfish and fickle. 
However there are similarities between Plato and Machiavelli, though Plato took the idealist route, how to establish stable and virtuous republic and avoid moral decay, Machiavelli opted for the realist route, more pragmatic and stable.

Machiavelli is often recognized as the cynic who put aside ethics and morality and focused on the distinction between the ends and the means. Scoterb analyzed that reality may be somewhere between Machiavelli and Mohan Das Karam Chand Gandhi to him the oneness of humanity lies in truth and denial of this caused violence and human sufferings he lived in the century of realism. To him that where there is only a choice between cowardice and violence; I would advice violence.

Modern South Asia twentieth century witnessed mass killing and violence Gandhi would rightfully consider he more realistic that our concepts on human nature, power, politics and ethics necessarily reflected in political decisions. Ibid, p.8.

However, Machiavelli simply cannot be ignored on the basis of that, he was the man of his century and his audience was $16^{\text {th }}$ century Italy. The task of the idealists and humanists is not to criticized or reject Machiavelli but to challenge the prevailing power of his ideas which exits yet today. Let's hope the days will come when our leaders are not compelled to sacrifice ethics morality for the politics and political expediency. This does not mean the challenge is not there. ibid, p.9

Thomas Hobbes was the part of that age of modernism in which defining changes occurred the end of the dominance of Aristotelian philosophy that human action were not followed by a special meta physical cause but typical tendencies of humans'. Modern Baconanian scientific approach to humans is followed by Thomas Hobbes. Civil humanism in Aristotle is not denied by Thomas Hobbes; but for the sake of promoting his concept of liberty he distanced from it. 2oaArran Gare,P.3

He presupposed $t$ he conception of humans. To him it was more effective and explicit rather to raise the questions like; what humans are and what distinguish them from other form of life; avoids theoretical assumptions in empirical inquiry.

He is bold enough to characterize humans as complex machines in motion. Moved by appetite and aversion," for seeing life is but a motion of limbs, the beginning where off we may not say That all automata, engines that move themselves by springs and wheels as doth a watch, have an so many wheels giving motion to the whole body; such as was intended by the artificer. 21thomas Hobbes, leviathan, introduction, p.1

Hobbes has been continuously; criticized for his radical ideas regarding humans. Despite the fact that many philosophers significant among them, John Locke and Jean lasque srousseau followed his approach to an extreme and also criticized him.

The high element of humans, rationality in all practical context people consented and alters the course of history, the ultimate goal which is to control them. Hobbes like any mechanist evaluating humans in terms of instruments, whose life is not more than a struggle for survival, they are cogs in a social order which simply denied their potential and the possibility of transforming this social order ibid, arrengare, p.4.

Anthropology from a pragmatic point of view established by Immanuel Kant, 1724-1804, the cultural dynamics owed to humans who are self conscious and accept the change with the unity of consciousness. Kant attempted to revive philosophical anthropology, in its universal sense, following Socratic Method, raising questions to seek answers. All the fundamental questions, he raises reckoned as anthropology. Kant is idealistic, on the assumption that, humans are free agents that he gives a place to ethics, but focusing on, 
consciousness; he also acknowledged the scientific knowledge. Kant's culture is a major teacher on this account, he made central to his philosophy the question, what are humans. To him, humans are essentially social and cultural. Life uphold higher aims, it's not a mere satisfying appetites but transcending self realization. The only driving force among them is to identify themselves and their communities. ibid, arrengare, p.5 6.

Herder acknowledges the role of culture in the development of humanity. To him, culture evolves through history; it is plural in nature and defined the whole way of life of a people. Herder ,s major contribution is the development of post mechanistic natural science, his reflections on human nature influenced many philosophers ,like hegel1770;1831, and Marx, 1818-1883, their political philosophies played vital role in the development of concepts of self realization, and culture which ultimately impact history and the human sciences . ibid,p6.

Clifford Geertz's most important contribution, the impact of the concept of culture on the concept of man influenced by the anthropological concept of culture deeply. He explains culture on the basis of two ideas to him, culture may be defined on the basis of concrete behavior patterns, such as customs, usages, traditions, habit clusters as has, by and large, been the case up to now, but as a set of control mechanism plans, recopies, rules, instructions for the governing of behavior. The second idea is that man is precisely the animal most desperately dependent upon such extra genetic, outside-the-skin control mechanism, for ordering his behavior.

Clifford Geertz, the impact of the concept of culture on the concept of man; a short excerpt from his influential collection, the interpretation of cultures.25 P6

Since 1960 the concept of culture has gone through radical changes, where culture is the key symbol of the field within anthropology, the discipline come under challenge because of the new understanding regarding power and history, for example one of the core example of the concept of culture has been the notion that culture is shared by all members of a given society but the subject matter of anthropology is to study the diverse societies of class race and ethnicity. If culture is shared, the task of the anthropologist became more complex as he has to raise the questions like, by whom, and in what ways and under what condition. The cultural world and its interaction produced explosion of studies, both contemporary and historical. ibid,p.8

Another important aspect of culture has been, its durability it is said that traditional societies have very slow pace of change, at least ruptured by, cultural contact. Anthropologist challenges this claim by saying, the durability of culture has dissolved and in almost every society the timeless tradition, in some cases, has been reinvented, and in some cases they are very stable. However, this requires sharp investigation, the question arises did the anthropologist accept the current situation and disown culture 27.

An excerpt from the editors; introduction', to their 1994 reader, culture, power and history, nicholas b. dirks, goeffeley and sherry b.ortner, eds.pp3,4. This critical assumption poses major al ternate view that anthropology being a huge discipline has origin in the humanities, the natural sciences and the social sciences. Moreover, it is a study of humans, past and present, to understand the complexities of cultures, across of all human history draws and builds upon knowledge. From the social biological sciences, as well as the humanities and physical sciences, most of all anthropology is an intellectual tradition and con tenuously have been the subject of analysis ,today anthropology is a global discipline, is anthropology beyond culture, sidle silver mans forward anthropology, as a discipline committed to the study of both, human evolution ,ethics and politics divers it of group life, the concept of 
culture provide a unifying thread, it's not good to abandon the concept, for others, anthropology, without culture is not only feasible but well established 28.

Sydel Silverman's, forward 'to a major new book on the culture concept; anthropology beyond culture[2002,ed.byrichardg.fox and Barbara J. King .philosophical anthropology as a developing tradition of inquiry played vital role in the dissolution of effective concept regarding humans based on mechanistic world view efforts were made to combat hobbesian tradition of thought, the theoretical scientists mobilized to write for the broader audience with the irreducible characteristics of humans, in doing this they have acknowledged and justifies the claim that humans are essentially social and creative arran gare,p.6.

More over they developed relationship between science and metaphysics and consequently revived the pre piously marginalized tradition of process philosophy, the question of what are humans were revived latter in the twentieth century to grapple the greatest obstacle to posing this question and arriving at an answer has been the division between the humanities and the sciences. The most profound ideas within the humanities were established by Hegel. Hegel was an idealist influenced by Kant, Herder and Plato. Hegel's ideas on human nature best be under stood in the light of recent work on the history of German philosophy in the late eighteenth and early nineteenth century, reformulate Kant's philosophy involved an appreciation of the essential characteristics of sociality of humans, that they only become humans through their relations to others, this development over came the abstract nature of ethical philosophy and provided much stronger stance for humans for acting ethically. ibid arrangare,p. 8

To Hegel; ,science may answers many questions, most of which answer question of the type, what happens if-, but there are questions which science cannot answer.-------it is simply because there is no room in science for questions like, what should i do, what ought I do,. It can answer question like,; what am I, but not; what should I be'.31

Over view of ethics, contribution to discussion march 2001 p.1contrary to this the leftist tendency is to limit politics to science, to them socialism is a worthy aim and adherence to this is taken to be the beginning and end of ethics. ibid,p.1

Hegel's philosophy of ethics may best be understood with reference to his philosophy of right to him before the Marxism human relations were not categorically distinct, kinship, political and production relations were merged. It was only during bourgeois society that a new dynamic force intervene called civil society between the state and the family. Both lost their significance the concept of family gradually disintegrated and the state is going to be empowered by the power of economics. The new relations emerged with the new nexus of cash and trade,' and of,; client and market ' this eventually cast subversion of all those relations constituting state and family. ibid,p. 2

Hegel viewed ethics not as innate human characteristics but in social perspective, to him ethics is social in nature, emerges when people entered in to relations though having conflicting interests. However, the ethical foundation of bourgeois society is the property relations, the money relation, alienate ethical values further accumulation of value as capital on one $h$ and the impoverishment of labor on the other ,consequently bourgeois ethics generates an irreconcilable conflict. ibid,p.3

Hegel's philosophy of human culture has various aspects including anthropology, law, morality social ethics which structured around family, civil society, state, religion, and philosophy.35 Paul Aston, on Hegel's ethics, p.3

To Hegel recognition of the freedom of others is possible only when one behave ethically which ultimately develop the selfhood. Hegel in synthesizing, all those developments in 
anthropology reformulate his ideas from Plato and Aristotle. The three interdependent dialectical patterns characterized human formative processes which operates through three different mediums such as the medium of language, the labor process which operates through the medium of the tool, and interaction on the basis of reciprocity which operates through the medium of moral relations,moral relations on being the part of culture developed human relations arran gare,p.9

Hegel in establishing humanized world up holding the quest to comprehend the world and to developed self conscious humans establish dialectics which are dependent upon each other at the same time dynamics of its own. Hegel developed the concept of humanity Marx hope that his, is .in Hegel there is more to history than the unfolding of the three dialectics, to Marx more important is the struggle between different classes in the ultimate progress of mankind. ibid,p.p9,10

Karl Marx is often criticized, either on the basis of outright rejection of ethics or that, moral deficit'. In his philosophy which ultimately caused ambiguity in his ethical discourse38, David Marjori banks, Marxism and ethics, review, p.1marx rarely engaged in moral ethical philosophy. Morality for historical materialism, does not stand apart from society and history, but is the part of the ideological and political superstructure, which arises on the basis of a mode of production. Ibid, p.39, ibid, p.1

There is a wide spread ambiguity upon to suggest that Marx did aim to escape ethics and morality. It is true that Marx takes the collective struggle of workers against capitalism as the moral obligation and opted an historical approach to freedom which is an ethical binding and emerges through historical struggle of proletariat against capitalism. Paul Black ledge analysis a coherent ethics can be found in Marx to him it must be understood within a wider whole- a view of society from the working class perspective. Marx did not reject morality, but rooted it in revolutionary practices40, Paul Black ledge, international socialism, Marxism and ethics, issue 120,p.2

Anew ethics and moral values are introduced by Marx that realization of freedom lies in the satisfaction of the basic needs, thus it was needs, which become integral social content. Marx, in this way did not oppose the modern liberal assumption, that moral behavior is the only parameter to control individualistic desires. Marx proposes alternative ethics, Hobbes like collective struggle against exploitation, and freedom, which is the virtue of the solidarity. Ethics before Marx, unlike modern philosophy is the relevance of the idea of good with human needs and desires paul black ledge, p.1.

\section{DeVELOPMENT}

The developments such as the global ecosystem the intensive role of culture in the life of humans is positive as well as negative, in the first place they have more potential, both to live for the higher aims of justice, power, and truth on the negative side, it is possible for them to enslave each other and to produce, social forms which, taking on a life of their own, enslave everyone to their dynamics, and delude people what they are doing again people do have the potential to rise up against the oppressive governance and establish new one, this is a unique creativity on the part of them. From the perspective of globalization and its impact on humans and their communities manifest fundamental changes, but what's important is to find out, whether change and development are interrelated as the essence of globalization lies in the most accessible branch of philosophy, the most ethical concept of good life while philosophers have centuries been in the quest to search out the dynamics of good life. While searching for the coherent conception of the 
humans, the frame works of a good life. The good life is a frame work of living that humans and their communities archive and sustain it ,as it fulfill humans as a human, .is the post globalization world, follow the world leaders to comprehend the significance of justice, role in extending justice, democratizing social and political relations and augmenting not undermining the global peace. Did they allow us to see that power is liberty, and empowerment lies in the good life guaranteed the new dialectical dynamics to liberate humanities must be not other than truth, justice and power? To participate in peace, therefore towards the common good of the humanity, the Hobbesian metaphor which has facilitated the enslavement of people rather to promote conditions for human civilization, denied any relevance to ethics and politics. The quest for justice signifies recognition of the community and its members and therefore recognizing the institutions and augmenting the ideals constituting them. In the context of the dynamics of the globalization reinvigorating the dialectical patterns of truth, justice and power and drive towards a better world with the inspiration of if to understand the humans and their possibilities, this is the real time to decide, whether they are complex machines survived through the struggle for survival. Is the new order of the nature lies in the survival of the fittest and this is unavoidable of the unfolding of the laws of nature which will filter out the less fit. What then would be the role of the state and the institutions/.if the aim is to eradicate humanity all the subsequent philosophy of ethics and politics where ethics is associated with the higher aim the realization of good life and politics implied to reach agreement on better arrangements, to realize higher element of rationality which engage in inquiry to realize the common good thereby comprehending place of humanity in the cosmos and therefore the ultimate ends of humanity is denied. The question of what it means to be humans, have been amongst the oldest and most important questions refer to the western philosophy and form an important domain of inquiry. Humans to them posses distinguish characteristics. What is the nature of these characteristics, do humans tend to have these characteristics. What is the nature of these characteristics? What causes them? What motivate them to act? Is human nature, independent of any external influence such as culture or socialization? These questions or more shaped the west human political philosophy and cast important implications in ethics, politics and anthropology. Moreover humans regarded both, as the source of the development of norms, traditions; portray ways of life as well as a source of constraint on living a good life. The notion of invariable human nature, however, has been an $\mathrm{n}$ important subject of enquiry, continues even in the modern times. The relative malleability has been argued in recent centuries--the early modernist Thomas Hobbes and jean masques. As Rousseau stated, "we do not know what our nature permits us to be thinkers such as Hegel, Marx argued against in variable human nature. Still more recent scientific perspective such as behaviorism modern psychology claim to be neutral in this regard to them, human's origin posses underlying mechanism, having capacities for change and diversity which ultimately is a violation of the classical, philosophical anthropology."

\section{CONCLUSION}

In conclusion ethical and moral identity is a determining and immutable dimension of an individual's self identity and that of the social whole, to which he or she is the part. If politics is a science moral and ethics provide or constitute organizational feature of a state that different segments of the society with the boundary maintenance and organizational dimensions necessary to maintain, and compete for socioeconomic resources. Both materialistic and idealist 
share one thing common, that is, the ultimate end of humans is self realization and good life Ethics and moral values continues to be a potent factor, even in the emerging new global order and its conflicts. The world no doubt has been drastically transformed, with unprecedented knowledge diffusion, remarkable development in almost every field of life, multicultural interaction and enhancement, increasing trade and development, much has been done, much still required to be addressed such as resource scarcity, financial instability, poverty, racism, injustice, disease, multi and intercultural conflicts, violence and war .The efforts are in progress to foster global perspectives on various common human issues as foundation for co- operation and progress .the integrating processes are accompanied by equally pervasive processes.

A trichotomy of fundamental socio-cultural/religious transformation in the global world. Nation state is continuously facing challenges from almost all spheres, such as political processes, transnational democracies, and interference in decision making. facing , convergent, social, national, transnational, sub-national. Ethno-cultural diversification consequently, declining borders, legitimacy, and trust. As Giddens rightly observed, 'in circumstance of accelerating global integration, the nation -state has become too small for the big problems and too big for the small problems of life'. the current transition resulted in the decreasing loyalty to national culture and growing contention for power by subnational groups3. As Hegel pointed out in his;, Philosophy of Right, 'the state and family, the old institutions losing their significance alongside a growing civil society, a domain of life intervened between the state and the family; the family is disintegrating and the state is overshadowed by the power of economics and the,; cash nexus,; the relations of client and service provider subverting all those relations which belong to state and family. The most obvious dual processes, both integrating and fractionating, shape the current civil society in to new ethno genesis and further proliferation.

Transformation in the global world, captured, even religion. Most of the thinkers of the 19th and 20th century were of the view that,' religion would either disappear or become attenuated with the expansion of modern institutions," religion neither disappear nor attenuated, rather became more vibrant and socially integrated. it has radically transformed and retreated, even in the vigorous form, in identity term, the resurgence of religious groups form a large market for religious ,spiritual books,tapes,music.5 Religion became political that it became significant in voting behavior and patterns, idealogy to shape public policy and political career, with reference to South and South East Asia, religion manifest itself in electoral politics, as Hindu fundamentalist, Shive Sena sweep elections in India, SriLanka, where religion remain an 'axcis of civil war' between two hostile groups, and Japan where the Sokka Gakki, known as,' clean government party; always become the part of government while never got majority in the polls, same is the case with Jamat -e-Islami in Pakistan, though have relatively greater importance and visibility in street politics remained strange to electoral politics6.

If god is gaining political voice, it is a god who must speak in nonsectarian and non -doctrinal language-(Yamane, 1997, 118-119) in Pakistan case, religion is declining increasingly as far as its true knowledge, message and spirit is concerned. The growing and thriving religious organizations, lack religious commitment; among commitment of all sorts, relational, familial and political' .the religion in Pakistan is becoming more secondary in the sense of; doctrinal content' and; in the terms of the ways that religion is experienced and practiced. In traditional societies, like Pakistan where conflicts between classes, ethnic groups are visible, among them sharper divide is religious and sectarian. Religious conflicts become more violent and threatening, when connected to sub -national group conflicts. 


\section{REFERENCES}

An excerpt from the editors, introduction to thier1994, reader,culture,power and history, Nicholas B. Dirks, Goeffeley, and Sherry B. Ortner,eds.pp 3,4.

Arran gare ,p.4

Arran gare,p.3

Arran gare,p. 6

Arran Gare,p.9

Arrangare, philosophical anthropology, ethics and political philosophy in an age of impending catastrophe,; cosmos and history; the journal of natural and social philosophy,volume5,no 2,2009.spage .3

Charles,,L.Harper and BryanF.LeBeau, social change and religion in America. Thinking Beyond Secularization,http;//are.as.wvu.edu/sochange.pp.10.11.

Clifford Geertz's the impact of the concept of culture on the concept of man, which was reprinted in his influential collection, the interpretation of a culture. It neatly sets a mid20thcentury view of culture in opposition to the typical enlighten view that the superficial diversity of culture masks an underlying- and readily discovered-universal uniformity.

David Marjoribanks,Marxism and Ethics, review,p.1

Garth Kimberling's insightful discussion of Socrates, great philosophers; Socrates 111.p.1

George R.Geiger, Philosophy and social change.v.1no1 spring1941, p.2

George R.Geiger, the Atioch review vol-50, No $1 / 250^{\text {th }}$ anniversary p. 21 .

GeorgeR.Geiger,Philosophy and social change,volume 1,number,1,spring 1941,p.17

Great philosophers, Socrates, 111,p.1

Hegel's ethics, overview of ethics. contribution to discussion march 2001,p.1

Historical theory and social change in John Dewey's philosophy byHenryW.Hodysh,p.1

Human nature from Wikipedia, the free encyclopedia, page.1.

Ibid ,p. 1

ibid, p.1

ibid, p. 2

ibid, p. 6

Ibid, p. 8

ibid ,Plato's views on human nature,p.1

Ibid, p,7

ibid, p.11.

ibid, p.3

ibid, p.7.

ibid, p.9

ibid, p9.

ibid, p, p.5,6

ibid,p. 13

Ibid,p.1

ibid,p.1

ibid,p.1

ibid,p.2

Ibid,p.3.

ibid, p.8

Ibid,p.8.

ibid,p.9.

Ibid,pp, 17,18

ibid,pp.15,17.

ibid.p.9 
ibidp. 2

IUAES AAS ASAANZ Conference 2011, Waltor jaros abstract from his paper, entitled, 'one human race-universal human identity and global citizen ship as foundation for social coopration and progress; horizon institute for, health promotion and global learning.

My paper, entitled, Thomas Hobbes, the $21^{\text {st }}$ century philosopher, written on his centenary celebrations published in European Studies.

On human nature, using allegory of the cave as reference, yahoo contributers, 2887759.html.p..1.

Overview of Hegelian Ethics;a contribution to discussion march 2001;http;//home.mira.net/andy/works/overeth.htm.,p.2

Paul blackledge, international socialism, Marxism and ethics,issue,120,p.2

Paul .Ashton on Hegel,.s ethics,p.3.http \ethical politics,org \seminars \asthetic.htm.

Paul Blackledge, international socialism, Marxism and ethics. http://www.isj.org.uk/ id=486.p Paul Blackledge,p5.

Paul Blacledge,International socialism;Marxism and Ethics.Freedom,desire, and Revolution,state university of Newyork,Albany,2012.p.5

Peri Roberts and Peter Sutch: An introduction to Political thought, Aconteporal Tool Kit. Edinburgh university press, p.75

Plato, apology, 38 a .

Plato's ethics, an over view, Stanford encyclopedia of philosophy, p.16. Plato's views 24

Plato's ethics, an over views tan ford encyclopedia of philosophy, p. 2,3.

Plato's ethics; an over view, Stanford, encyclopedia of philosophy, p.2

Scot Erb, reading revolutions; great minds, great thoughts, Machiavelli and power politics,p.3

Social change and religion in America,p11

Socrates, Stanford encyclopedia of philosophy , p.9

Sydel Silverman,s forward, to a major new book on the cultures concept; cited from culture, definitions, histories and discussions,p.10.

Thomas hobbes,leviathan,introduction,p.1

Submit your next manuscript at- www.abcjournals.net

$A B C$ Journals is a unique forum to offer open access to all of its articles.

Now ABC Journal's portfolio is over nine journals, which publish both online and in print. 